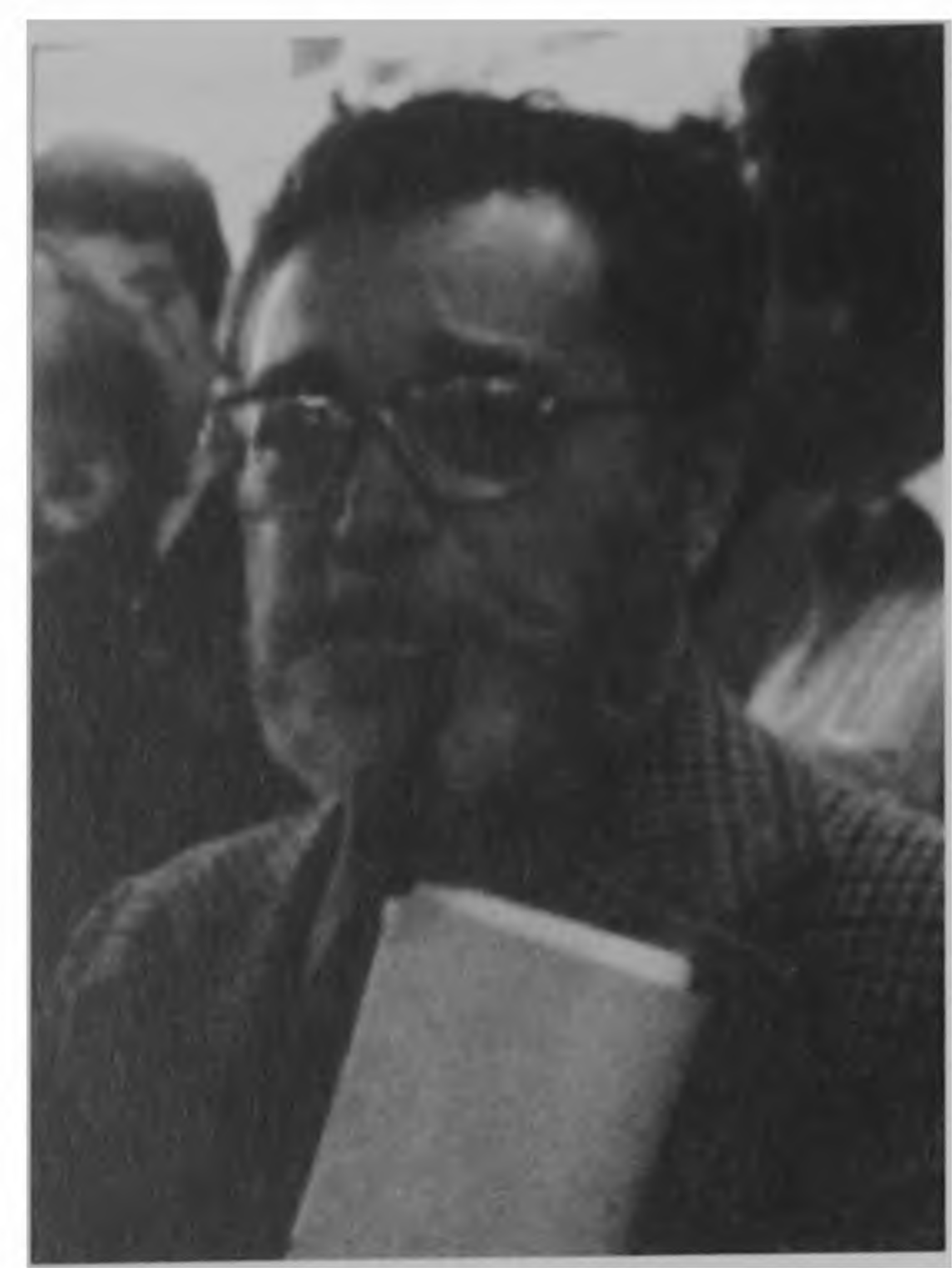

\title{
EduARdo Corona
}

\author{
Carlos Alberto Cerqueira Lemos
}

Não é fácil escrever sobre Corona nestes dias após seu falecimento aos 79 anos, porque a sua presença parece ainda estar viva e atuante, dando-nos a impressão que foi ali e já volta. Mesmo doente, nesses últimos anos, agia com desempenho e não se amedrontava em sair de casa para qualquer tipo de atividade, mesmo sabendo-se frágil. Fomos testemunhas disso, recentemente em uma reunião do $I A B$, quando arquitetos veteranos se manifestavam sobre 0 exercício da profissão. Em dado momento, cambaleou, e sofrendo o grande desconforto causado pelo coração comprometido, pálido como uma folha de papel, apoiando-se na borda da mesa, exigiu que a sessão continuasse e só depois de terminada a reunião solicitou que fosse transportado ao hospital.

A reunião de pessoas, sobretudo colegas, era o meio propício à sua personalidade, que se revelava e se expandia bem-humorada, fosse qual fosse 0 tema tratado - a conciliação sempre foi a sua meta e, para isso, nunca foi intransigente. Transitava entre os seus pares com a maior desenvoltura.

No exercício da profissão, foi mais do que um arquiteto, bom arquiteto por sinal, como atestam vários de seus projetos. Foi, antes de tudo, um aglutinador de posições e de idéias dentro de sua classe. Ajudou na fundação de escolas de arquitetura e todos estamos a nos lembrar de sua atuação na FAU, nas faculdades de Mogi das Cruzes e de Guarulhos. Ali foi um bom professor e disso fomos testemunhas oculares como seu assistente da cadeira Teoria da Arquitetura, talvez 
por uns dez anos. Estranhamente, enquanto era dedicadíssimo no preparo das aulas, era tolerante e complacente com os alunos desatentos, como se não fizesse questão alguma que aprendessem. Suas aulas teóricas eram expostas com muita clareza e vagarosamente desenvolvia suas idéias, não se importando muito com a receptividade das explicações. Para ele, aluno que fosse bom aprendia tudo com facilidade e, quem não fosse, nunca iria tomar conhecimento da matéria, mesmo que tivesse outras oportunidades. A repetição de ano era uma bobagem. Nunca reprovou um aluno sequer. Talvez fosse mesmo exigente nos exames do vestibular, em que atuou por muitos anos, porque ali estava selecionando futuros arquitetos. No cotidiano, no entanto, jamais exigiu coisa alguma dos outros.

Agiu também por muito tempo como conselheiro do Crea, mas ali seu espírito conciliador sempre esteve atento às normas, às regras e às leis, sabendo desatar como ninguém os nós cegos surgidos nos processos que recebia para relatar. Tomava decisões com incrível rapidez e extremo bom senso. Sabia simplificar as coisas facilmente, sendo inimigo das discussões intermináveis. Sabia de pronto colocar cada coisa em seu lugar.

Com seu tino agudo de observação escreveu durante anos nos boletins do $I A B$, no qual sempre defendeu os aspectos éticos da profissão e os interesses da classe, sem, contudo, assumir posições políticas radicais. Intimamente, era um homem de esquerda, talvez desde os dias de estudante no Rio, quando conviveu com Oscar, como seu estagiário e desenhista. Publicamente, no entanto, sua posição política era estar sentado em cima do muro, o que irritava o pessoal do partidão. Nunca se importou com isso.

Enfim, as mil facetas do Corona impedem que se fale com precisão e só podemos tachá-lo de homem hábil no convívio com seus pares e, não podemos esquecer, muito competente na prancheta de arquiteto, como atesta o seu projeto da Faculdade de História e Geografia da USP

Fomos verdadeiramente amigos por 50 anos.

\section{Carlos Alberto Cerqueira Lemos}

Professor titular aposentado do Departamento de História da Arquitetura e Estética do Projeto e orientador no curso de pós-graduação FAUUSP.

(texto reproduzido do Informativo FAUUSP - maio 2001)

Foto: Cristiano Mascaro 